\title{
Demographic Effects on Quality of Life among Superintendents
}

\author{
By Debra J. Heffernan* \\ Teresa A. Wasonga ${ }^{\dagger}$
}

The purpose of this study was to explore quality of life and demographic influences among Illinois school district superintendents. Quality of Life was defined as "individual's subjective evaluation of the degree to which his or her most important needs, goals, and values are fulfilled" (Frisch, 1992, p. 29) leading to general state of happiness or well-being. Quantitative survey (Quality of Life Inventory) data came from 341 (40\%) superintendents. Of these respondents, 87 were females and 254 were males. Female superintendents recorded higher mean scores in perceived levels of quality of life in 13 of 16 life areas. A significant effect size was found between superintends scoring "high" and those scoring "average" on overall quality of life. The findings indicate that either the superintendency has less adverse effects on female superintendents' quality of life or female responses to the job mitigates the adverse effects.

Keywords: demographics, female school leaders, gender, quality of life, superintendents

\section{Introduction}

In 1909, Ella Flagg, the first female superintendent of the Chicago Public Schools, predicted that women would eventually "rule the schools" due to the innate ability of the female gender and the nature of the field of education (Dobberteen, 1996). More than one hundred years have passed since her prediction, and although more than $20 \%$ of school district superintendencies in the state of Illinois are held by women, white males continue to hold the sovereign reigns over public education in the United States (Glass, Bjork \& Brunner, 2000). Historically, women are over-represented in the classroom setting and under-represented in administrative positions. For example, while Shakeshaft (1991) found that more than $80 \%$ of elementary teachers and $50 \%$ of secondary teachers were female in 1985; a significant under-representation of female administrators is noted in the research (Kowalski, McCord, Petersen, Young, \& Ellerson, 2011; Glass, Bjork, \& Brunner, 2000).

By 1992, the American Association of School Administrators (AASA) found that the number of female superintendents nationwide had doubled to $6.6 \%$, and again doubled by 2000 to $13.1 \%$ (Glass, Bjork, \& Brunner, 2000). But, despite advances in training and increased numbers of females completing advanced degree programs, majority of school leadership positions continue to

\footnotetext{
${ }^{*}$ School Administrator, Lincoln-Way Area Special Education Cooperative District 843, USA.

${ }^{\dagger}$ Professor, Northern Illinois University, USA.
} 
be held by white males (Kowalski et al., 2011; Brunner \& Kim, 2010; Glass, Bjork \& Brunner, 2000). It is therefore clear that the shortage of females in the superintendency is less likely the absence of women in the profession or educational preparation. In fact, women aspiring to, or are currently superintendents meet and exceed preparation and expected requirements (Brunner \& Kim, 2010). One area that has not been given adequate consideration in the superintendency, despite findings that this position is personally demanding, professionally challenging, stressful (Glass, 2000) and emotionally draining (Wallace, 2010); is its influence on work related quality of life outcomes - "a measure of life satisfaction that may complement symptom oriented measures of psychological functioning" in everyday life (Frisch, Comell, Villanueva \& Rezziaff, 1992, p. 92) and whose outcomes may have impact on mental health and general well-being (Frisch, 1998). As in other leadership roles, research has found that potential for job-related stress and the time requirements for the superintendency has been a deterrent, especially to females seeking the superintendency (Glass, 2000; Newton, 2001; Tebben \& Coxwell, 2001). However, Brunner and Kim (2010) disagree. In their research, they found that women's experiences and career paths render them better prepared than men for the stresses of the superintendency. Though limited, this research shows the need for more studies.

In studying women in educational administration, a variety of frameworks have been applied including career paths, education levels, personal demographics, characteristics of female educators, as well as barriers that they encounter. However, the quandary addressed by the current study is the subjective judgments of superintendents about their quality of life in relation to their work. Demographics are explored as possible correlates to quality of life and underrepresentation of females in the superintendency. Thus, the theoretical framework for this study is the quality of life inventory by Frisch (1998; 1994).

\section{Review of the Literature}

The Quality of Life Inventory focuses on individual well-being defined as the subjective relative degree of excellence in living to the extent that life is satisfying or enjoyable beyond mere subsistence, survival, or longevity (Frisch, 1998, p. 29). Excellence is denoted by living that is worthwhile and exemplified by among others meaningful work, self-realization, or decent standard of living. Frisch $(1998,1994)$ identified 16 areas of life that together contribute to human happiness and fulfillment, including: health, self-esteem, goals and values, money, work, play, learning, creativity, helping, love, friends, children, relatives, home, neighborhood and community. Frisch (1994) intimates a connection between an individual's satisfaction with life and the importance or the value accorded that particular area of life. Areas of life that are accorded higher levels of satisfaction and importance are presumed to have more significant impacts in determining overall quality of life (Frisch, 1994). 
In other words, the smaller the perceived incongruities between an individual's aspirations and accomplishments, the higher the levels of positive perceptions of quality of life for that individual. Frisch (1998) found that satisfaction with a life area is not only essential criterion for mental health, it is also necessary for positive outcomes in job satisfaction and well-being. Varying environments, including contexts, content, and processes in and outside of the work place variably impact perceptions of the importance and satisfaction with quality of life.

As explained by Dawis, Lofquist and Weiss's in their "Work Adjustment Theory" (1984), multiple environments that exist in every individual's life, including home, school and work relate to and influence each other and overall perception of life. Achieving correspondence in one environment may affect a person's ability to achieve and maintain correspondence in another. Women, more so than men, have been found to balance multiple roles in their attempts to succeed or maintain correspondence in both professional and personal lives (Brunner \& Kim, 2010; Marks, 2001; Martire et al., 2001). For example, while attending to professional work, women account for a disproportionate high number of household and child-care responsibilities regardless of their employment status (full-time/part-time), or the changing societal attitudes and expectations regarding gender roles (Yoder, 2003).

The significance of this study is in the likely impact of job-related stress on quality of life areas among educational leaders, specifically superintendents. The study explores subjective perceptions of quality of life and the demographic (gender, age, years spent in the classroom, school district enrollment, number of years spent in office as a superintendent, and whether or not there were children residing within the home) effects among Illinois school superintendents. The urgency for this study are the changing landscape for the superintendency including expected increases in school enrollment, the changing demographics, and the dearth in school leaders who can produce desired results for all children irrespective of their backgrounds (National Center for Education Statistics, 2010). These changes require leaders with courage to undertake actions that may be stressful but needed for deep change, social justice, deep democracy, and effectiveness rather than efficiency in schools (English, 2008).

Historically, the superintendency was initiated in the mid 1800's, with individuals appointed to oversee the day-to-day operations of a number of schoolhouses. By 1860, 27 different cities with school districts had created a position entitled superintendent (Glass, Bjork, \& Brunner, 2000). By 1875, there were 29 superintendents, and as noted by the first female Chicago superintendent, Ella Young, "the expansion of cities necessitated reorganization of one-room school centers into hierarchical configurations of roles to make schools run more efficiently-principles of scientific management were used, including assembly line approaches and factorymanagement styles" (Young, 1916, p. 357). As the numbers of superintendents grew, the dynamics of the position evolved, changing from "cleric to master educator to expert manager to chief executive officer for the board of 
education" and operations manager (Carter \& Cunningham, 1997, p. 297; Callahan, 1966). This evolution has continued, and the superintendent of the new millennium has been described, in corporate terms, as the CEO of the school district (Hoyle, Bjork, Collier, \& Glass, 2005).

With this evolution, the role of the superintendent has, according to Brown, Swendson and Hertz (2007), "become a hotbed of political focus in recent years. No longer is it sufficient for the designated leader...to be an accomplished educator and respected person" (p. 5); they solve conflicts between different segments of the community ...communicate effectively with the news media and the general public; work collaboratively with staff members and motivate people to meet common goals; manage the business and financial sides of complex organizations, and coordinate efforts with municipal leaders and human-service providers (Carter \& Cunningham, 2002, p. 42).

In comparing the differences between yesterday's and today's superintendent, Cambron-McCabe, Cunningham, Harvey, and Koff (2005) confirmed the changing role of the superintendent in a changing world. Hoyle, Bjork, Collier, and Glass (2005) also likened the role of the superintendent to that of a CEO for the school district. Other research focusing on the context of the superintendency show that it is difficult to make accurate generalizations regarding the superintendency because of variances in conditions of work and size of school districts (Kowaslki et al., 2011; Glass \& Franceschini, 2007; Hoyle, Bjork, Collier, \& Glass, 2005). However, these researchers found common problems that impact the superintendency irrespective of gender or size of school including: inadequate financial resources; high stress; lack of time; and the necessity to contend with varying agendas of special interest groups.

From a historical perspective, women were absent from the workforce, including schools until World War II (Blount, 1998). But since then, specifically in the field of education, the percentage of females becoming teachers has increased and over time surpassed men. However, the percentage of females in educational leadership positions, particularly in the position of school superintendent, has remained low (Kowalski et al., 2011; Glass, 2000; Shakeshaft, 1991). Skrla (2000) found that men are forty times more likely to advance into the superintendency position compared to women. This phenomenon dates back to the late $18^{\text {th }}$ century when teaching was done mainly by men because of biblical interpretations known as the "injunction of St. Paul," where women were not permitted to teach (Shakeshaft, 1991, p. 23). But, by the close of the colonization period, boys and girls ages four through seven, were getting trained in the home by "teacher-housewives" (Shakeshaft, 1991). Labor shortages in the years between 1830 and 1900 and the spread of common schooling throughout the territories and states saw more women chosen to teach. In addition, relatively low wages associated with teaching made it difficult to procure male candidates (Blount, 1998). Consequently, more women were able to enter the profession. The female teacher workforce, which was $57.2 \%$ by 1880 , grew to more than $70 \%$ by 1900 (Shakeshaft, 1991). Laws, however, restricted women's places in school administration, 
with different qualifications existing for female versus male administrators. Thus, only "a handful of women held administrative positions... (with women) found(ing) their own schools (to) serve as ...chief administrators" (Shakeshaft, 1991, p. 33).

The first thirty years of the twentieth century, described as the "Golden Age for Women in School Administration" (Hansot \& Tyack, 1981), saw a larger number of women obtaining administrative positions, due, in part, to the feminist movement, and partly, women's right to vote in local elections. In 1910 , even though women were subsequently able to elect other women to educational administrative positions as county superintendents, these positions were lower in status, power, and salary.

In the $21^{\text {st }}$ century, the number of female superintendents continues to lag substantially behind the number of males, mostly white, occupying this same position (Glass, Bjork, \& Brunner, 2000). To this end, it has been suggested that some females currently occupying superintendency positions were "drafted" (military perspective) as opposed to planning for the job (Torres, 2004). A variety of studies show that females rarely seek the superintendency as part of their career plans; instead they were usually promoted from within and mentored to these positions or recruited (Glass, 2000; Torres, 2004). Brunner and Kim (2010) discount ideas that women are not formally or personally prepared for, or seek the superintendency. Instead, like Skrla (2000), they argue that gendered norms and negative social construction of women create barriers for women in seeking the superintendency. In trying to understand the dearth of women in the superintendency, these authors have recommended studies of other factors that may serve as attractants or deterrents to the job, including demographics and quality of life.

\section{The Superintendency and Demographics}

Recent studies by the AASA show that the vast majority of American superintendents continue to be white and male (Kowalski et al., 2011; Glass \& Franceschini, 2007; Glass, Bjork, \& Brunner, 2000). The average age of superintendents has increased consistently, from 43 in 1923, to 50 in 1992 and 52 in 2000 (Glass, Bjork, \& Brunner, 2000). Most superintendents were married and grew up in rural areas or small towns, and unlike those in previous studies, superintendents in the $21^{\text {st }}$ century spent more years in the classroom (Glass et al., 2000). Female superintendents were found to have fewer overall years in the superintendency and less experience in coaching (typical male pathway to the superintendency). Additionally, female superintendents were more likely to have come from elementary backgrounds, and served in smaller districts (Brunner \& Kim, 2010; Glass, Bjork, \& Brunner, 2000; Paddock, 1978); spent more years in the classroom (Glass, Bjork, \& Brunner, 2000); older when appointed to their first superintendency (Brunner \& Kim, 2010; Glass, 2000); entered the field of teaching earlier but were older when seeking advanced degrees and administrative positions (Kowalski et al., 2011; Paddock, 1978); and often discontinued their teaching careers to raise children 
as they reported "waiting for their children to get older before pursuing positions that make heavy demands on their time" (Glass, Bjork, \& Brunner, 2000, p. 79).

Marital status of superintendents as an area of interest to research consistently shows a significantly larger number of unmarried females in the superintendency (Glass, Bjork, \& Brunner, 2000; Paddock, 1978). Higher divorce rates among female superintendents were substantiated by Glass, Bjork and Brunner (2000), who found four times the number of female superintendents $(23 \%)$ reporting they were single compared to their male counterparts (5.3\%). Schuster and Foote (1990) found that women superintendents were more often single and childless. In their study, female superintendents were six times more likely to remain single and averaged 1.2 fewer children. Being married and being female were linked to a higher level of conflict with negative effects on career and job satisfaction. In addition, as found by Glass (2000), female superintendents and assistant superintendents did not feel they spent enough time with family and friends, who sometimes reciprocated with resentment. Other studies indicate that family responsibilities and the balance between family and career are obstacles to administrative advancement among women (Tebben \& Coxwell, 2001; Brunner, 2000; Glass, 2000). Citing women as having more responsibility for the home, family life, and child care; Gordon and Whelan-Berry's (2004) study of life and job satisfaction found that spousal or "significant other" support was more important to women. Other factors cited by women as impacting their life and job satisfaction in the work place include: job characteristics; human relations; making a difference in children's lives; serving as a role model for teachers and young women; facilitating change in schools; networking; skill variety and opportunities; and, organizational cooperation and caring (Tebben \& Coxwell, 2001; Paddock, 1978).

Besides the aforementioned, job satisfaction or the lack there of among women has also been described as a function of women's lack of knowledge regarding discriminatory practices waged towards them in the work place (Weaver, 1979). Weaver argued that women tended to report high job satisfaction because they were unaware of the discrimination leveled towards them, especially, in pay and position. For example, the Ledbetter Case, in which a female senior Goodyear managerial employee was paid less than the lowest-paid man despite her seniority and years of service. She learned of this financial inequity nearing retirement, and although the judgment against Goodyear was overturned by the Supreme Court due to a 180 day statute of limitations protecting businesses, this precipitated the Lilly Ledbetter Fair Pay Act (McLaughlin, 2007). Studies show that the median weekly salaries for female adults over 24 years of age possessing master's, professional or doctoral degrees in 2002 were $25 \%$ lower than those of men possessing comparable degrees, and by 2005, women's salaries continued to lag behind men's by $23 \%$ (National Committee on Pay Equity, 2007). This trend persists in the education sector. Despite the fact that a larger percentage of female superintendents (33\%) against men (12\%) possessed doctorate degrees three decades ago 
(Paddock, 1978) and 56.8\% (female) against 43.7\% (male) in the year 2000 (Glass, Bjork, \& Brunner, 2000); more females lead smaller districts with more than half earning less money than the average superintendent's salary in the each state. The persistence of these differences may translate into differences in quality of life by race, gender, marital status or age among superintendents. In the general population though, demographic differences have been found to occur in both levels of satisfaction and in predictors of quality of life experiences (Lehman, Rachuba, \& Postrado, 1995).

\section{Quality of Life (QOL)}

QOL is defined as "an individual's subjective evaluation of the degree to which his or her most important needs, goals, and values are fulfilled" (Frisch, 1992 , p. 29) leading to a general state of happiness or well-being. Frisch explains that one's happiness or satisfaction with highly valued areas of life is essential for mental health, positive outcomes in psychotherapy, and absence of disease. His research found links between depression and dissatisfaction with constructs of life satisfaction and well-being. Deterrents to better quality of life and job satisfaction are cited in a variety of studies within and outside of the fields of educational administration. They include: the characteristics of the administrative position itself; job attributes like stress and number of hours worked; role conflicts in marriage and familial relationships; gender-based issues; organizational factors; career advancement opportunities and salary; and educational-levels and age of respondents (Brunner \& Kim, 2010; Skrla, 2000; Glass, 2000; Newton, 2001; Tebben \& Coxwell, 2001; Eckman, 2002; Mavin, 2001). Other researchers have uncovered links between personal demand factors that impact quality of life and the limited number of female applicants in educational administrative positions. Newton (2001), for example, found that female students enrolling in educational administrative courses cited both the potential for job-related stress and the time requirements for these positions as factors limiting the positive impacts of job attributes associated with administration. Tebben and Coxwell (2001) found that long hours associated with administrative positions, particularly the superintendency, deter females from applying. Organizational factors identified by female administrators as detractors of job satisfaction and contributors to the desire to resign from leadership roles, include: current leaders; decision-making processes and institutional decisions; limited upward mobility; lack of mentoring and feelings of isolation; lack of organizational support for professional growth; lack of organizational support for the administrator herself; limited advancement opportunities; lower salary; and health problems (Grogan, 2000; Reisser \& Zurfluh, 1987). This study focused on quality of life because research about it in school setting is limited. 


\section{Methodology}

A survey design, employing quantitative measures, was utilized in the current study to examine quality of life among school district superintendents in Illinois. The study used the Quality of Life Inventory (QOLI), a 32 item survey developed by Frisch (1994) to assess a person's satisfaction and the importance attached to the sixteen different areas of life identified by Frisch (health, self-esteem, goals and values, money, work, play, learning, creativity, helping, love, friends, children, relatives, home, neighborhood and community). The QOLI has been used in a variety of clinical settings, involving over 3,927 clients (Frisch et al., 2005). Reliability test-retests coefficients for the QOLI were found to range between .08 and .91with internal consistency coefficients ranging from .77 to .89 (Frisch et al., 1992). In terms of validity, Frisch et.al. report that QOLI has significant positive correlations with seven related measures of subjective well-being (SBW) including peer rating and clinical interview measures.

The QOLI provides a score that indicates an individual's judgment on the importance of and satisfaction with each life area based on a three-point rating scale for importance ("Not at all important"- 0 to "Extremely important"- 2); and a six-point rating scale for satisfaction ("Very Dissatisfied"- -3 to "Very Satisfied"- +3) (Frisch, 1994). The quality of life score, known as QOLI Raw Score, for an individual is calculated by averaging the weighted satisfaction ratings (Satisfaction*Importance) with the number of non-zero importance ratings of the 16 areas of life. Responses resulting in negative value denote an area of life that are worthy of treatment. Frisch (1994) has identified four categories in which respondents may fall depending on the score: high (raw scores ranging from 6.0 to 3.6; percentile rating of $81 \%-99 \%$ ), average (raw scores ranging from 3.5 to 1.6 ; percentile rating of $21 \%$ to $80 \%$ ), low (raw scores ranging from 1.5 to 0.9 ; percentile rating of $11 \%$ to $20 \%$ ), and very low (raw scores ranging from 0.8 to -6.0 ; percentile rating of $1 \%$ to $10 \%$ ).

In addition to QOLI, demographic data, including professional and personal information was gathered through the survey. Professional information requested included: the number of years spent in the classroom; other administrative positions held; numbers of years spent as superintendent; the number of districts in which the individual held superintendency positions; the highest education level attained; teaching certificates held/highly qualified subject areas; the size of the district (number of students); and the setting of the district (rural, suburban or urban). Personal information requested included: age; marital status; number of children at home and their ages; whether the respondent was planning on remaining in the role of superintendent until retirement; and whether the superintendent had been solicited or actively pursued the position.

Target population for the study was all superintendents serving in Illinois Public School Districts at the time of the study. Of the 868 identified superintendents, $27.76 \%$ (241) were female, more than double the percentage determined ten years earlier in the 2000 study by Glass, Bjork, \& Brunner. A 
total of 868 survey inventories were sent out via post office mail, $348(40.1 \%)$ surveys and/or inventories were returned. Of these, 341 were complete, 87 $(25.51 \%)$ from female superintendents, and 254 (74.49\%) from males.

Data was analyzed through both descriptive and inferential statistics to assess the value of the sixteen areas of quality of life based on perceived importance, perceived satisfaction and weighted satisfaction for superintendents. $t$ tests, ANOVAs, and correlation equations were employed to determine differences and relationships among the 16 areas of life and demographics respectively.

\section{Findings}

\section{Demography}

The percentage of female superintendents in this study was $27.7 \%$ twice the $13.2 \%$ reported in a national study ten years earlier (Glass Bjork, \& Brunner, 2000) and higher than the $24.1 \%$ reported by Kowalski et al. (2011). Although progress has been made in the last 20 years, women continue to be under-represented in school leadership considering the percentage of women (84\%) teaching in schools (National Center for Educational Reform, 2011). The average age of superintendents appears to be increasing and the age gap between males and females is decreasing (Brunner \& Kim, 2010). As reported by Glass et al. (2000), the average age has increased from 43 years (1923), to 50 years of age (1992), to 52 years (2000). In the current study, the average age for male superintendents was 51.7 years and 52.7 for females.

In this study both male and female respondents averaged longer mean number of years (8.4 and 11.4 year respectively) in the classroom compared to Glass et.al.(2000) study (5 and 10 years respectively). In terms of the number of years spent in the current superintendency, the differences were negligible, with females reporting 5.6 and their male counterparts, 5.4 years. The mean number of superintendencies held by male superintendents was $28.6 \%$ higher than females. Ten percent more female superintendents, almost two-thirds, reported they were serving their first superintendency. Female superintendents also relocated less frequently.

The number of married or partnered men in the current study remained fairly similar to Glass, Bjork, \& Brunner's (2000) study, dropping only slightly from $94.7 \%$ to $94.3 \%$. The number of married female respondents, however, more than doubled, from $41.2 \%$ in the 2000 study to $84.7 \%$ in the current study. However, the number of divorced female superintendents was more than double that of their male counterparts, $7.1 \%$ and $2.9 \%$ respectively. In addition, the number of females that remained single was almost triple the number of their male counterparts ( $7.1 \%$ and $2.4 \%$ respectively). While $63.5 \%$ female and $36.5 \%$ male superintendents reported no children currently residing in their homes, a higher percentage of male superintendents reported living with one, two, three, four or more children within the home. This is consistent with 
findings by Schuster \& Foote (1990), who found that female superintendents were more likely to be childless, and averaged 1.2 less children than males.

When comparing education levels (doctorate) by gender among Illinois superintendents during the 2010/2011 school year with those from Glass, Bjork, \& Brunner's 2000 study, the gap has narrowed in favor of women. What was once almost a $13 \%$ gap (Glass et al.) narrowed to $3 \%$ in the current study (50.57\% of the females and $47.64 \%$ of their males). Regarding administrative positions held prior to the current superintendency, both male and female respondents had held principalships at the same rates $(79.9 \%$ and $79.8 \%$ respectively). However, female superintendents were more likely to have served as assistant superintendents and in dual roles of principalship and superintendency. While $67.7 \%$ male and $42.4 \%$ female superintendents possessed secondary level teaching certificates, $26.9 \%$ males and $40 \%$ females possessed elementary level. In addition, more female superintendents were certified in special education and had served in special educational administrative positions, a finding supported in Glass, Bjork, \& Brunner's study (2000). This study also confirmed that females were more likely to serve as superintendents in K-8 (52.9: 39.4\%) and rural (58.8: 56.7\%) school districts while men were more likely to serve in high school (13.4: 9.4\%), unit school (45.5: 37.6\%), suburban school (39.6: 38.8\%), and urban school (3.3: 2.4\%) districts. In regards to student enrollment, female superintendents were found to lead districts with approximately $40 \%$ fewer students than their male counterparts (average 1,239 students and 2,053 students respectively). In addition, none of the female superintendents in the current study reported leading districts with 7,500 and above; $5 \%$ of the male superintendents reported leading districts of this size.

Responding to how they obtained the job, $54.2 \%$ of the female were solicited and $42.2 \%$ pursued the job; $43.3 \%$ of males were solicited and $44.1 \%$ pursued the job. A larger number of males (95\%) compared to females $(90 \%)$ planned on retiring in the superintendency. Three times more female superintendents $(7.1 \%: 2.4 \%)$ were unsure regarding their future plans to retire in this position. 
Table 1. Scores in Different Areas of Life by Gender in Perceived Levels of Importance, Perceived Levels of Satisfaction, and Perceived Levels of Weighted Satisfaction among All Superintendents, Males, and Female

\begin{tabular}{|c|c|c|c|c|c|c|c|c|c|}
\hline & \multicolumn{3}{|c|}{$\begin{array}{l}\text { Perceived Levels of Importance } \\
\text { (PLI) }\end{array}$} & \multicolumn{3}{|c|}{ Perceived Levels of Satisfaction (PLS) } & \multicolumn{3}{|c|}{$\begin{array}{c}\text { Perceived Levels of Weighted } \\
\text { Satisfaction (PLWS) } \\
\end{array}$} \\
\hline & All & Males & Female & All & Males & Female & All & Males & Female \\
\hline Number & $(336)$ & $(250)$ & $(86)$ & $(336)$ & $(250)$ & $(86)$ & $(336)$ & $(250)$ & $(86)$ \\
\hline Life Area & M(S.D) & $\mathrm{M}(\mathrm{S} . \mathrm{D})$ & $\mathrm{M}(\mathrm{S} . \mathrm{D})$ & $\mathrm{M}(\mathrm{S} . \mathrm{D})$ & $\mathrm{M}(\mathrm{S} . \mathrm{D})$ & $\mathrm{M}(\mathrm{S} . \mathrm{D})$ & $\mathrm{M}(\mathrm{S} . \mathrm{D})$ & M(S.D) & $\mathrm{M}(\mathrm{S} . \mathrm{D})$ \\
\hline Health & $1.79(.41)$ & $1.77(.43)$ & $1.86(.35)$ & $1.70(1.38)$ & $1.72(1.37)$ & $1.64(1.41)$ & $3.26(2.54)$ & $3.22(2.58)$ & $3.33(2.45)$ \\
\hline Self-Esteem & $1.72(.46)$ & $1.70(.47)$ & $1.78(.42)$ & $2.21(.90)$ & $2.21(.91)$ & $2.23(.89)$ & $3.90(1.98)$ & $3.86(2.01)$ & $4.02(1.91)$ \\
\hline Goals/Values & $1.84(.37)$ & $1.82(.38)$ & $1.87(.34)$ & $2.33(.76)$ & $2.28(.75)$ & $2.47(.79)$ & $4.36(1.72)$ & $4.25(1.70)$ & $4.66(1.74)$ \\
\hline Money & $1.07(.47)$ & $.08(.45)$ & $1.05(.53)$ & $1.97(1.03)$ & $1.94(.99)$ & $2.05(1.15)$ & $2.01(1.53)$ & $2.04(1.43)$ & $1.92(1.82)$ \\
\hline Work & $1.51(.53)$ & $1.48(.54)$ & $1.62(.49)$ & $2.04(1.20)$ & $2.00(1.22)$ & $2.14(1.16)$ & $3.22(2.24)$ & $3.31(2.22)$ & $3.49(2.32)$ \\
\hline Play & $1.52(.55)$ & $1.53(.54)$ & $1.47(.57)$ & $1.31(1.59)$ & $1.44(1.46)$ & $.93(1.86)$ & $2.18(2.66)$ & $2.36(2.54)$ & $1.62(2.93)$ \\
\hline Learning & $1.57(.53)$ & $1.52(.54)$ & $1.71(.48)$ & $1.93(.96)$ & $1.86(.92)$ & $2.15(1.05)$ & $3.15(1.95)$ & $2.95(1.82)$ & $3.75(2.21)$ \\
\hline Creativity & $1.26(.64)$ & $1.19(.64)$ & $1.44(.63)$ & $1.36(1.27)$ & $1.35(1.23)$ & $1.38(1.41)$ & $1.98(2.17)$ & $1.86(2.00)$ & $2.34(2.59)$ \\
\hline Helping & $1.56(.55)$ & $1.52(.58)$ & $1.69(.47)$ & $1.70(1.21)$ & $1.69(1.17)$ & $1.76(1.35)$ & $2.95(2.25)$ & $2.87(2.14)$ & $3.20(2.57)$ \\
\hline Love & $1.77(.43)$ & $1.78(.43)$ & $1.74(.46)$ & $2.25(1.30)$ & $2.28(1.24)$ & $2.15(1.45)$ & $4.16(2.35)$ & $4.18(2.45)$ & $4.07(2.78)$ \\
\hline Friends & $1.46(.56)$ & $1.40(.57)$ & $1.62(.49)$ & $1.76(1.36)$ & $1.66(1.37)$ & $2.05(1.31)$ & $2.84(2.41)$ & $2.60(2.34)$ & $3.55(2.51)$ \\
\hline Children & $1.79(.48)$ & $1.80(.46)$ & $1.76(.55)$ & $2.47(1.04)$ & $2.44(1.07)$ & $2.53(.96)$ & $4.58(2.24)$ & $4.54(2.23)$ & $4.68(2.27)$ \\
\hline Relatives & $1.47(.57)$ & $1.43(.57)$ & $1.57(.54)$ & $1.85(1.29)$ & $1.79(1.30)$ & $2.03(1.26)$ & $3.02(2.40)$ & $2.85(2.37)$ & $3.51(2.42)$ \\
\hline Home & $1.39(.56)$ & $1.35(.56)$ & $1.50(.55)$ & $2.21(1.02)$ & $2.15(1.05)$ & $2.38(.94)$ & $3.19(2.16)$ & $3.04(2.14)$ & $3.66(2.15)$ \\
\hline Neighborhood & $1.25(.55)$ & $1.22(.55)$ & $1.35(.53)$ & $2.05(1.13)$ & $2.01(1.23)$ & $2.16(1.12)$ & $2.75(2.07)$ & $2.62(2.09)$ & $3.11(1.99)$ \\
\hline Community & $1.26(.54)$ & $1.25(.53)$ & $1.28(.55)$ & $1.63(1.34)$ & $1.57(1.36)$ & $1.79(1.27)$ & 2.2392.19) & $2.13(2.19)$ & $2.54(2.18)$ \\
\hline
\end{tabular}




\section{Quality of Life}

Scores on perceived levels of importance (PLI), perceived levels of satisfaction (PLS) and perceived levels of weighted satisfaction (PLWS) with quality of life are presented in Table 1 . The four areas of life receiving the highest scores from all superintendents on PLI were health, goals/values, love, and children, with goals/values receiving the highest mean score. The mean scores for PLI were higher for female superintendents in 12 of the 16 life areas, with the exception of money, play, love, and children. Male superintendents scored higher means in PLI in the life areas of love and children while females scored higher means in the life areas of health and goals/values. The four areas receiving the lowest mean scores on PLI for all superintendents were the life areas of money, creativity, neighborhood, and community, with money receiving the lowest mean score. Male superintendents scored lower means in the life areas of creativity, neighborhood, and community while females scored a lower mean in the life area of money. The two areas with the largest differences in mean scores on PLI between males and females were creativity and friends. Most superintendents reported average scored in quality of life. Table 2 presents numbers of superintendents scoring very low, low, average and high on general quality of life.

Table 2. Number of Superintendents Scoring Very Low to High on Quality of Life Inventory

\begin{tabular}{|l|c|c|c|}
\hline Classification & All Superintendents & Males & Females \\
\hline Very Low & 11 & 9 & 2 \\
\hline Low & 21 & 16 & 5 \\
\hline Average & 183 & 145 & 38 \\
\hline High & 120 & 79 & 41 \\
\hline
\end{tabular}

The four areas of life receiving the highest mean scores on perceived levels of satisfaction (PLS) from all superintendents were the life areas of children, goals/values, self-esteem, and home, with children receiving the highest mean scores for both genders. The mean scores for PLS were higher among female superintendents in 13 of the 16 life areas, with the exception of the areas of health, play, and love. The four areas receiving the highest mean scores among male superintendents were the life areas of children, love, goals/values and self-esteem. Although male superintendents scored a higher mean in the PLS on life area of love, love was not rated in the top four by females. Instead females scored higher in the life areas of children, goals/values, self-esteem, and home, with their score on children representing the highest mean score for PLS. The lowest mean scores for males, females and the composite group were in play (men) and creativity (female and all). The two areas with the largest differences in mean scores on PLS between males and females were the life areas of play (for men) and friends (for women).

The four areas receiving the highest mean scores on perceived levels of weighted satisfaction (PLWS-combination of satisfaction and importance) 
from all superintendents were the life areas of children, goals/values, love, and self-esteem. The mean scores for the PLWS were higher for female superintendents in 13 of the 16 life areas with the exception of money, play, and love. Male superintendents scored a higher mean in the life area of love, while females scored higher mean averages in the life areas of children, goals/values, and self-esteem. The life area of children received the highest mean score for PLWS by both groups. The four areas receiving the lowest mean scores in PLWS for all superintendents were the life areas of play, money, creativity, and community. Male superintendents scored a lower means in the life areas of creativity and community while females scored a lower means in areas of money and play.

A $t$-test was conducted to compare superintendents' perceptions of PLI in the sixteen different areas of quality of life by gender. Significant differences at $\mathrm{p}<.05$ level were found in life areas of work, helping in favor of females, and home in favor of males and, at $\mathrm{p}<.01$ in life areas of health, relatives, and neighborhood, all in favor of females (Table 3). In comparing perceptions on PLS by gender, a $t$-test revealed significance differences at $\mathrm{p}<.05$ in goals/values, learning, and friends in favor of females and, at $\mathrm{p}<.01$ in play in favor of males (Table 4). In comparing perceptions of PLWS (QOLI Raw scores) by gender, the $t$-test revealed significant differences at $\mathrm{p}<.05$ in goals/values, relatives, home, and neighborhood, and at $\mathrm{p}<.01$ in learning and friends in favor of females and play at <.05 in favor of males (Table 5).

Table 3. t-Test Showing QOLI Life Areas that were Significantly Different in Perceptions of Importance (PLI) among Superintendents by Gender

\begin{tabular}{|l|c|c|c|c|c|}
\hline \multirow{2}{*}{ Life Area } & \multicolumn{2}{|c|}{$\begin{array}{c}\text { Levene's Test for } \\
\text { Equality of Variances }\end{array}$} & \multicolumn{3}{|c|}{$t$-test for Equality of Means } \\
\cline { 2 - 6 } & $\mathrm{F}$ & Sig. & $t$ & $\mathrm{df}$ & $\begin{array}{c}\text { Sig. } \\
(2 \text {-tailed })\end{array}$ \\
\hline Work & 8.84 & .00 & -2.26 & 334 & $.02^{*}$ \\
\hline Learning & 19.60 & .00 & -2.73 & 334 & $.01^{* *}$ \\
\hline Creativity & 1.78 & .18 & -3.02 & 334 & $.01^{* *}$ \\
\hline Helping & 17.99 & .00 & -2.32 & 334 & $.02^{*}$ \\
\hline Friends & 5.86 & .02 & -3.05 & 333 & $.00^{* *}$ \\
\hline Home & .18 & .67 & -2.05 & 334 & $.04^{*}$ \\
\hline
\end{tabular}

**Significant at $\mathrm{p}<.01$ level; *Significant at $\mathrm{p}<.05$ level

Table 4. t-Test Showing Quality of Life Areas that were Significantly Different in Perceptions of Satisfaction (PLS) among Superintendents by Gender

\begin{tabular}{|l|c|c|c|c|c|}
\hline \multirow{2}{*}{ Life Area } & \multicolumn{2}{|c|}{$\begin{array}{c}\text { Levene's Test for } \\
\text { Equality of Variances }\end{array}$} & \multicolumn{3}{|c|}{$t$-test for Equality of Means } \\
\cline { 2 - 6 } & $\mathrm{F}$ & Sig. & $t$ & $\mathrm{df}$ & $\begin{array}{c}\text { Sig. } \\
(2 \text {-tailed) }\end{array}$ \\
\hline Goals/Values & .35 & .56 & -1.97 & 334 & $.05^{*}$ \\
\hline Play & 13.06 & .00 & 2.63 & 334 & $.01^{* *}$ \\
\hline Learning & 4.31 & .04 & -2.41 & 332 & $.02^{*}$ \\
\hline Friends & 1.51 & .22 & -2.27 & 333 & $.02^{*}$ \\
\hline
\end{tabular}

**Significant at $\mathrm{p}<.01$ level; *Significant at $\mathrm{p}<.05$ level 
Table 5. t-Test Showing Quality of Life Areas that were of Significantly Different in Perceptions of Weighted Satisfaction (PLWS) among Superintendents by Gender

\begin{tabular}{|c|c|c|c|c|c|}
\hline \multirow[t]{2}{*}{ Life Area } & \multicolumn{2}{|c|}{$\begin{array}{c}\text { Levene's Test of } \\
\text { variances } \\
\text { for Equality }\end{array}$} & \multicolumn{3}{|c|}{$t$-test for Equality of Means } \\
\hline & $\mathrm{F}$ & Sig. & $t$ & df & $\begin{array}{c}\text { Sig. } \\
\text { (2-tailed) }\end{array}$ \\
\hline Goals/Values & .54 & .46 & -1.97 & 333 & $.05 *$ \\
\hline Play & 3.98 & .05 & 2.26 & 334 & $.02 *$ \\
\hline Learning & 5.17 & .02 & -3.28 & 332 & $.00^{* * *}$ \\
\hline Friends & 1.02 & .31 & -3.13 & 333 & $.00 * *$ \\
\hline Relatives & .26 & .61 & -2.06 & 33 & $.04 *$ \\
\hline Home & .00 & .95 & -2.14 & 334 & $.03^{*}$ \\
\hline
\end{tabular}

**Significant at $\mathrm{p}<.01$ level; *Significant at $\mathrm{p}<.05$ level

A $t$-test found a significant difference between males and females on their QOLI Raw score (weighted score) with a higher mean for females $(t=-2.259$; $\mathrm{p}=.025)$. In addition, ANOVA revealed significant difference between superintendents scoring "high" and those scoring "average" on overall quality of life inventory. The effect size (.79) indicated that the difference had a large effect. A larger percentage of female superintendents rated their quality of life as high compared to males (48\% and 32\% respectively). Approximately $10 \%$ of male respondents rated their quality of life as low or very low, compared to $8 \%$ of their female peers. ANOVA equations were also used to determine areas of life that were significantly different in perceived levels of importance (PLI), perceived levels of satisfaction (PLS), and perceived levels of weighted satisfaction (PLWS) for all superintendents by demographic areas of age, years spent in the classroom, school district enrollment, years spent in office as a superintendent, and whether or not there were children residing in the home. Demographic areas showing significant differences are presented in Tables 6 (PLI), 7 (PLS), and 8 (PLWS).

Table 6. ANOVA Equation Showing Areas of Life where there were Significant Differences in Perceived Levels of Importance (PLI) by Demography for All Superintendents

\begin{tabular}{|l|c|c|c|c|c|c|}
\hline \multicolumn{1}{|c|}{$\begin{array}{c}\text { Demographic } \\
\text { Area }\end{array}$} & Life Area & $\begin{array}{c}\text { Sum of } \\
\text { Squares }\end{array}$ & df & $\begin{array}{c}\text { Mean } \\
\text { Square }\end{array}$ & F & Sig. \\
\hline Age & Creativity & 27.03 & 40 & .68 & 1.80 & $.00^{* *}$ \\
\hline $\begin{array}{l}\text { Years in } \\
\text { Classroom } \\
\text { Enrollment }\end{array}$ & Friends & 19.30 & 40 & .48 & 1.65 & $.01^{* *}$ \\
\hline Years in Office & Children & 10.47 & 29 & .36 & 1.61 & $.03^{*}$ \\
\hline Kids at Home & Health & 29.91 & 158 & .19 & 1.57 & $.01^{* *}$ \\
\cline { 2 - 8 } & Neighborhood & 13.51 & 26 & .52 & 1.82 & $.01^{* *}$ \\
\cline { 2 - 8 }
\end{tabular}

$* *$ Significant at $\mathrm{p}<.01$ level; **Significant at $\mathrm{p}<.05$ level 
Table 7. ANOVA Equation Showing Areas of Life where there were Significant Differences in Perceived Levels of Satisfaction (PLS) for All Superintendents by demographics in 16 Areas of Life

\begin{tabular}{|l|c|c|c|c|c|c|}
\hline \multicolumn{1}{|c|}{$\begin{array}{c}\text { Demographic } \\
\text { Area }\end{array}$} & Life Area & $\begin{array}{c}\text { Sum of } \\
\text { Squares }\end{array}$ & df & $\begin{array}{c}\text { Mean } \\
\text { Square }\end{array}$ & F & Sig. \\
\hline $\begin{array}{l}\text { Years in } \begin{array}{l}\text { Classroom } \\
\text { Enrollment }\end{array} \\
\text { Years in Office }\end{array}$ & Relatives & 76.17 & 29 & 2.63 & 1.64 & $.03^{*}$ \\
\hline \multirow{4}{*}{ Kids at Home } & 199.31 & 158 & 1.26 & 1.83 & $.00^{* *}$ \\
\cline { 2 - 8 } & Meath & 85.22 & 26 & 3.28 & 1.89 & $.01^{* *}$ \\
\cline { 2 - 8 } & Mearning & 24.20 & 7 & 3.46 & 3.33 & $.00^{* *}$ \\
\cline { 2 - 8 } & Creativity & 26.28 & 7 & 3.76 & 2.34 & $.02^{*}$ \\
\cline { 2 - 8 } & Home & 27.10 & 7 & 3.87 & 3.89 & $.00^{* *}$ \\
\hline
\end{tabular}

**Significant at $\mathrm{p}<.01$ level; *Significant at $\mathrm{p}<.05$ level

Table 8: ANOVA Equation Showing Areas of Life where there were Significant Differences among Superintendents in Perceived Levels of Weighted Satisfaction (PLWS)by Demographics

\begin{tabular}{|l|c|c|c|c|c|c|}
\hline $\begin{array}{l}\text { Demographic } \\
\text { Area }\end{array}$ & Life Area & $\begin{array}{c}\text { Sum of } \\
\text { Squares }\end{array}$ & df & $\begin{array}{c}\text { Mean } \\
\text { Square }\end{array}$ & F & Sig. \\
\hline Age & Creativity & 296.13 & 40 & 7.40 & 1.69 & $.01^{* *}$ \\
\hline $\begin{array}{l}\text { Years in } \\
\text { Classroom } \\
\text { Enrollment }\end{array}$ & Learning & 151.19 & 29 & 5.21 & 1.39 & $.10^{*}$ \\
\cline { 2 - 8 } & Money & 434.15 & 157 & 2.77 & 1.43 & $.03^{*}$ \\
\hline Kids at Home & Creativity & 86.59 & 7 & 12.37 & 2.66 & $.01^{* *}$ \\
\cline { 2 - 8 } & Home & 68.70 & 7 & 9.81 & 2.15 & $.04 *$ \\
\hline
\end{tabular}

**Significant at $\mathrm{p}<.01$ level; *Significant at $\mathrm{p}<.05$ level

Correlation analysis indicated that money had a low $(\mathrm{r}=.31 ; \mathrm{p}<.01)$ positive correlation with the PLWS score while goals/values and children had a moderately high $(\mathrm{r}=.572 ; \mathrm{p}<.01$ and $\mathrm{r}=.446 ; \mathrm{p}<.01$ respectively) positive correlation with PLWS score. Creativity $(\mathrm{r}=.645 ; \mathrm{p}<.01)$ and paly $(\mathrm{r}=.613$; $\mathrm{p}<.01$ ) had the highest positive correlations with PLWS score for all superintendents.

\section{Reflection}

A smaller percentage of females continue to occupy the superintendency in the state of Illinois as is nation-wide. At the same time, they continue to spend more years as classroom instructors prior to their first administrative positions. And although both male and female superintendents spent time as school principals, females occupy fewer superintendency positions and are predisposed to leading in smaller, elementary, and rural districts. They are also more likely to possess elementary level teaching certificates.

What we found surprising in this study was that despite feelings of trepidation among female superintendents, as well as time constraints, earning less, being single, they experienced higher levels of quality of life in general, 
and higher mean scores in their perceived levels of weighted satisfaction. How do we explain this level of satisfaction and fewer numbers of women in the superintendency? First, from a deficit stand point, as Weaver (1997) argued, women may be reporting higher quality of life because they are unaware of the discrimination leveled towards them, especially, in pay and position. A number of female superintedents commented that they were not in this job for "money, but for the children" or "passion" or "to make a difference." Similar arguments were found in the work of Tebben and Coxwell (2001) and Skrla (2000) where women reported that the best thing(s) about being a woman in leadership included: affecting students' lives and making a difference; serving as a role model for teachers and younger women; facilitating change in the schools; and, networking. They ignore the fact that limited basic resources that come with money do have negative impacts on quality of life (in the areas of money, play, love). Areas of life in which women scored lower require resources that come with the use of disposable money (play and love). In other words, people need time out of work to play, vacation, and have fun; but they also require disposable income to pay for such activities and when females earn less than their male peers and work longer, both play and fun time are reduced. Absent disposable income and time is likely to have negative impacts on play and love. On the other hand, the women may have developed resiliency, acquiring skills to balance their personal lives and work (Skrla, 2000; Dawis, Lofquist, \& Weiss, 1984) and built capacity to overcome challenges of the job because of previous experiences (Brunner \& Kim, 2010). Challenging previous experiences associated with their career path may provide immunity or higher tolerance to the negative effects of both personal and professional tribulations that come with the office of the superintendent among females. Due to these experiences, they are likely to developed better coping systems and therefore experience more satisfying lives in the superintendency despite lower earnings, taking on more responsibilities within the home setting (Yoder, 2003), and limited time for "self" or play or love. Findings indicating higher levels of quality of life experienced by female superintendents fit with "Work Adjustment Theory" (Dawis, Lofquist, \& Weiss, 1984) which explains that we live in multiple environments and experience these environments differently. Women are likely experiencing the superintendency differently from men, hence perceiving higher quality of life.

On the other hand, male superintendents experienced a lower quality of life generally compared to women even though they tend to pursue the job, earn more money, and are more likely to be married. They scored lower in a significantly higher number of areas of life (13 of 16) that impact quality life. They were also younger entering the superintendency, they serve in larger and urban school districts that are more likely experiencing greater magnitudes of social, economic and political issues, and yet they spent less time preparing for this job (in the classroom). The irony of the aforementioned is the fact that leadership skills associated with women including humanistic collaborative leadership is the type of leadership recommended for the dynamic school environment (Marks, 2001). It is likely that males are having trouble balancing 
their roles as efficiently as the women in the superintendency. For example, the Role Balance Theory (RBT) (Marks, 2001; Martire et al., 2001) that describes juggling as an "act" that women engage in throughout their lives in an effort to balance multiple roles is a more relevant skill for effective and relevant leadership today. Brunner and Kim (2010) and Grogan (2010) find that women, because of their experiences in multiple roles in their career paths are resilient and amenable and therefore predisposed to do better in balancing professional and personal lives; hence higher scores in quality of life.

\section{Conclusion}

In seeking to understand men and women's experiences together (Shakeshaft, 1991), this study shows that female superintendents have advantage over males in the area of quality of life. These findings are not only encouraging to women in the superintendency, they provide promise and hope for women aspiring to the superintendency, and the profession where majority educators are women. At the same time, the findings point to the concern about the quality of life among male superintendents, and capacity to communicate this information to current and aspiring superintendents. If satisfaction with life is an essential criterion for job satisfaction, physical and mental health, and positive outcomes in well-being (Frisch, 1998); both males and females deserve to have a high quality of life in the superintendency.

Based on findings in this study, we find that the superintendency has lesser adverse effects on the physical and psychological health and general well-being of females compared to males. In other words, women experience higher quality of life that enables them to stay physically healthy, emotionally stable, and psychologically effective in the superintendency despite the challenges of the job. Therefore, they should not only vigorously solicit and compete for the superintendency and other leadership at all levels of school administration, they should be noted for their resilience and qualities that make them uniquely and better qualified to be CEOs of school districts. Recent research shows that women are, in fact, more apposite for the superintendency formally, experientially, and personally (Brunner \& Kim, 2010). The work of Brunner and Kim has debunked unfounded claims by Glass (2000) that women are themselves the cause of the dearth of women in the superintencency. Like Skrla (2000), they argue that gender norms, gender biases, and social construction of women and femininity as less effective in school leadership, are the barriers to women seeking the superintendency. Grogan (2010) has gone further and reasoned that women should reshape leadership rather than lead as men. Earlier, Skrla (2000) and more recently Brunner and Kim (2010), contend that what has been considered weakness in women leadership, including collaboration, juggling profession and family commitments, empathy, relational leadership; are emerging as the qualities needed to provide quality school leadership today. This study adds to this body of research. Women seated in the superintendency are better prepared to "rule schools." Their 
higher quality of life indicates that they are coping better with the stresses of the superintendency.

\section{References}

Blount, J. M. (1998). Destined to rule the schools: Women and the superintendency, 1873-1995. Albany, NY: State University of New York Press.

Brown, T. F., Swendson, S. H. \& Hertz, K. V. (2007) Identifying the relative strength of Glasser's five basic needs in school superintendents. Journal of Scholarship and Practice, 3(4).

Brunner, C. C. (2000). Principles of power: Women in the superintendency. Albany, NY: State University of New York.

Brunner, C. C., \& Kim, Y. (2010). Are women prepared to be school superintendents? An essay on the myths and misunderstandings. Journal of Research on Leadership, 5(8), 276-309.

Callahan, R. E. (1966). The superintendent of schools. Eugene, OR: ERIC.

Cambron-McCabe, N, Cunningham, L. L., Harvey, J., \& Koff, R. H. (2005). The superintendent's fieldbook: A guide for leaders of learning. Thousand Oaks, CA: Corwin Press.

Carter, G. R., \& Cunningham, W. G. (1997). The American school superintendent: Leading in an age of pressure. San Francisco: Jossey-Bass.

Dawis, R.V. \& Lofquist, L.H. (1984). A psychological theory of work adjustment. Minneapolis,

MN: University of Minnesota Press.

Dobberteen, K. W. (1996). Perceptions of women superintendents regarding their roles and career constraints: A comparative study. (Doctoral dissertation, Northern Arizona University, 1996). (UMI No. 9636610)

Eckman, E. W. (2002, January). Woman high school principals: Perspectives on role conflict, role commitment, and job satisfaction. Journal of School Leadership, 12(1), 57-77.

English, F. W. (2008). Anatomy of professional practice: Promising research perspectives on educational leadership. Lanham, MD: Rowman \& Littlefield Education.

Frisch, M. B. (1992). Use of the Quality of Life Inventory in problem assessment and treatment planning for cognitive therapy of depression. In. A. Freeman \& F. M. Dattilio (Eds.), Comprehensive casebook of cognitive therapy (pp. 27-52). New York: Plenum.

Frisch, M. B. (1994). Quality of Life Inventory: Manual and treatment guide. Minneapolis, MN: Pearson Assessments (formerly NCS Assessments).

Frisch, M. B. (1998). Quality of life therapy and assessment in health care. Clinical Psychology, Science and Practice, 5(1), 19-40.

Frisch, M. B., Clark, M. P., Rouse, S. V., Rudd, M.D., Paweleck, J. K., Greenstone, A., et al. (2005). Predictive and treatment validity of life satisfaction and the Quality of Life Inventory. Assessment 12(1), 66-78.

Frisch, M. B., Comel, J., Villanueva, M. \& Retzlaff, P. J. (1992). Clinical validation of the Quality of Life Inventory: A measure of life satisfaction for use in treatment planning and outcome assessment. Psychological Assessment, 4(1), 92-101.

Glass, T. (2000). Where are all the women superintendents? School Administrator, 57(6) 28-32. 
Glass, T. E., Bjork, L. \& Cryss Brunner, C. (2000). The study of the American school superintendency 2000: A look at the superintendent of education in the new millennium. Arlington, VA: American Association of School Administrators.

Glass, T. \& Franceschini, L. A. (2007). The state of the American school superintendency: A mid-decade study. Lanham, MD: Rowman \& Littlefield Education.

Gordon, J. R., \& Whelan-Berry, K. S. (2004). It takes two to tango: an empirical study of perceived spousal/partner support for working women. Women in Management Review, 19(5/6), 260-273.

Grogan, M. (2000). Laying the groundwork for a reconception of the superintendency from feminist postmodern perspectives. Education Administration Quarterly, $36(10), 117-142$.

Grogan, M. (2010). "Conclusion: women around the world reshaping leadership for education", Journal of Educational Administration, 48(6), 782 - 786.

Hansot, E., \& Tyack, D. (1981). The dream deferred: A golden age of women school administrators (Policy Paper No. 81-C2). Stanford, CA: Stanford University, Institute for Research on Educational Finance and Government.

Hoyle, J. R., Bjork, L. G., Collier, V., \& Glass, T. (2005). The superintendent as CEO: Standards-based performance. Thousand Oaks, CA: Corwin Press.

Kowalski, T. J., McCord, R. S., Petersen, G. J., Young, I. R., \& Ellerson, N. M. (2011). The American school superintendent: 2010 decennial study. Lanham, MD: Rowman \& Littlefield Education.

Lehman, A. F., Rachuba, L. T., \& Postrado, L. (1995). Demographic influences on quality of life among persons with chronic mental illness. Evaluation and Program Planning, 18(2), 155-164.

Marks, S. R. (2001). Role balance among White Married Couples. Journal of Marriage and Family, 63, 1083-1098.

Martire, L. M., Parris, M. A., \& Townsend, A.L. (2001). Centrality of women's multiple roles: Beneficial and detrimental consequences for psychological wellbeing. Psychology and Aging, 15, 148-156.

Mavin, S. (2001). Women's career in theory and practice: Time for change? Women in Management Review, 16(4), 183-192.

McLaughlin, B. (2007). Congress passes Lilly Ledbetter Fair Pay Act. Associated Content. Retrieved from http://bit.ly/2gFCZ5p.

National Committee on Pay Equity. (2007). Wage Gap Remains. Retrieved from http://bit.ly/11NRaAS.

National Center for Education Reform (2011). Profile of teachers in the U.S. 2011. Retrieved from http://bit.ly/1hd20vc.

National Center for Education Statistics. (2010). Search for Public School Districts. Retrieved from http://bit.ly/2gSSAwi.

Newton, R. M. (2001). An investigation of variables that influence teacher attraction for the principalship. Paper presented at the Annual Meeting of the Mid-South Educational Research Association (30 ${ }^{\text {th }}$, Little Rock, AR, November 13-16, 2001). Retrieved October 12, 2005 from ERIC (ED470422)

Paddock, S. C. (1978). Careers in educational administration: Are women the exception? Oregon University, Eugene. Center for Educational Policy and Management. Retrieved February 9, 2006 from ERIC (ED149468)

Reisser, L. J., \& Zurfluh, L. A. (1987, Summer). Female administrators: Moving up, or moving out? Journal of the National Association of Women Deans, Administrators and Counselors, 50(4), 22-29.

Schuster, D. J., \& Foote, T. H. (1990, February). Differences abound between male 
and female superintendents. School Administrator, 47(2), 14-16, 18-19.

Shakeshaft, C. (1991). Women in educational administration. Updated Edition. Newbury Park, CA: SAGE Publications, Inc.

Skrla, L. (2000). The social construction of gender in the superintendency. Journal of Educational Policy, 15(3), 293-316.

Tebben, S., \& Coxwell, M. (2001). Administrators report on best of times, worst of times. Women in Higher Education, 10(11), 38.

Torres, D. (2004). Hispanic female superintendents: making history as leaders of urban city districts (New York, Puerto Rico). (Doctoral dissertation, Fordham University, 2004). (UMI No. 3134452)

Wallace, J. (2010). Facing "reality": including the emotional in school leadership programmes. Journal of Educational Administration, 48(5), 595 - 610.

Weaver, C. N. (1979, May). The irony of the job satisfaction of females. Personnel Administrator, 24(5), 70-73.

Yoder, J. D. (2003). Women and gender: Transforming psychology, $2^{\text {nd }}$ ed. Upper Saddle River, NJ: Prentice Hall.

Young, E. F. (1916, July 1-8). A reply. Journal of Proceedings and Addresses of the National Education Association. 